\title{
A Federal Reserve System Conference on Research in Applied Microeconomics
}

$\underline{\text { Thomas A. Garrett }}$

\begin{abstract}
This article summarizes some of the papers presented at the System Applied Microeconomics Conference organized and hosted by the Federal Reserve Bank of St. Louis on May 5-6, 2011. This annual conference brings together economists from the Federal Reserve District Banks across the Federal Reserve System and the Federal Reserve Board to present their latest economic research.
\end{abstract}

Federal Reserve Bank of St. Louis Review, November/December 2011, 93(6), pp. 455-62.

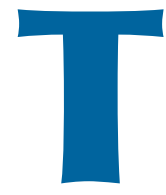
he Federal Reserve Bank of St. Louis hosted the annual System Applied Microeconomics Conference on May 5-6, 2011. The papers presented at the conference, some of which are summarized in this article, showcased research in the areas of public policy, education and human capital, labor markets, and housing and consumer finance during the Great Recession. ${ }^{1}$

\section{ANALYSIS OF PUBLIC POLICY}

The first group of papers focused on public policy issues. In "Assessing the Evidence on Neighborhood Effects from Moving to Opportunity," Aliprantis provides a new framework and a robust instrument to estimate neighborhood effects using data from the Moving to Opportunity for Fair Housing (MTO) program. The MTO program, a 10-year research project, combines tenantbased rental subsidies with housing counseling

1 View the conference agenda at http://research.stlouisfed.org/ conferences/appliedmicro/agenda.html. Not all papers presented at the conference are included herein because authors were given the option to not include their papers in these proceedings. to help poor families move from poor urban areas to less-poor neighborhoods. Aliprantis's framework improves on earlier methods for studying the effects of housing mobility programs by distinguishing between program and neighborhood effect.

In "The Spending and Debt Response to Minimum Wage Hikes," Aaronson, Agarwal, and French explore how minimum wage increases influence spending and debt accumulation by minimum wage earners. They find that (i) both consumer spending and debt accumulation increase after a minimum wage increase and (ii) most spending induced by such an increase goes toward financing durables. The authors' empirical findings are consistent with an augmented bufferstock model in which households are collateral constrained.

Given the recent decline in aid from state to local governments, in "Designing Formulas for Distributing State Aid Reductions," Zhao and Coyne develop a new formula for allocation of such funds. Their formula improves on other methods because it is based on the underlying fiscal health of local governments rather than commonly used ad hoc measures.

Thomas A. Garrett is an assistant vice president and economist at the Federal Reserve Bank of St. Louis.

(C) 2011, The Federal Reserve Bank of St. Louis. The views expressed in this article are those of the author(s) and do not necessarily reflect the views of the Federal Reserve System, the Board of Governors, or the regional Federal Reserve Banks. Articles may be reprinted, reproduced, published, distributed, displayed, and transmitted in their entirety if copyright notice, author name(s), and full citation are included. Abstracts, synopses, and other derivative works may be made only with prior written permission of the Federal Reserve Bank of St. Louis. 


\section{HUMAN CAPITAL}

A second group of papers focused on the topic of human capital. In "The Role of Schools in the Production of Achievement," Canon states that previous research has been unable to simultaneously consider the three types of inputs believed to influence student skills: ability, family inputs, and school inputs. Canon uses parents' savings for higher education as a measure of ability in an empirical framework that corrects for the endogeneity of the three inputs. Unlike earlier studies that do not address the simultaneity among the three inputs, Canon presents evidence that school inputs are important for the formation of student skills when controlling for the ability to learn.

In "Economic Literacy and Inflation Expectations: Evidence from a Laboratory Experiment," Burke and Manz present new experimental evidence on heterogeneity in the formation of inflation expectations. They conduct a laboratory experiment in which subjects complete a set of inflation-forecasting exercises in a simulated economic environment. They find that the subjects' demographic characteristics play a small role in the variation of their inflation expectations, but economic literacy plays a large role in explaining the accuracy of inflation forecasts.

In "Financial Literacy and Mortgage Equity Withdrawals," Duca and Kumar examine whether an individual's financial literacy influences the decision to make or not make mortgage equity withdrawals. Their results indicate that the financially literate are 3 to 5 percentage points less likely to withdraw housing equity but that this result does not apply to home equity lines of credit.

\section{LABOR MARKET ISSUES}

A third group of papers, of which one is summarized here, focused on labor market issues. In "When Does the Labor Market Consider You a Smoker and Do You Care?” Armour, Hotchkiss, and Pitts explore the wage differential between smokers and nonsmokers. Using a switching regression framework with unknown sample selection, they find that smokers do face a wage penalty. However, this penalty is not a result of smokers having lower productivity but rather of the set of personal characteristics smokers bring to the workplace. The authors also find that individual smoking behavior is responsive to the earnings penalty associated with smoking.

\section{LESSONS FROM THE GREAT RECESSION AND HOUSING CRISIS}

A fourth group of papers, of which one is summarized here, examined housing and consumer finance during the Great Recession. In "Financing Constraints and Unemployment: Evidence from the Great Recession," DuyganBump, Levkov, and Montoriol-Garriga examine the link between small-business lending and unemployment during the Great Recession. They argue that if a reduction in lending to small businesses influences unemployment, then unemployment should increase more in smaller firms with greater dependence on bank financing. The authors find that individuals working in sectors with high external financial dependence, of which a large portion is small businesses, were more likely to become unemployed. However, they find no difference in the likelihood of unemployment for workers in small and large firms in sectors with low external financial dependence.

\section{CONTRIBUTIONS}

The following section provides more-detailed summaries of selected conference papers.

\section{"Assessing the Evidence on Neighborhood Effects from Moving to Opportunity"}

Building on recent developments in the program evaluation literature, Aliprantis defines several treatment-effect parameters and estimates and interprets some of these parameters using data from the MTO program. The evaluation framework makes a clear distinction between (i) program effects from intent-to-treat and treatment-on-the- 
treated parameters and (ii) neighborhood effects from local-average-treatment-effect parameters. This distinction helps to clarify that, although the results from MTO are informative about the design of housing mobility programs, they are only informative about a small subset of neighborhood effects. Furthermore, examination of the local average treatment effect identifying assumptions helps to illustrate the limitations of searching for exogenous variation in one causal variable while abstracting from all others.

Aliprantis presents empirical tests for instrument strength that show that MTO induced large changes in neighborhood poverty rates but remarkably little variation in many of the other neighborhood characteristics believed to influence outcomes. He argues that this reinterpretation of the MTO data stresses the importance of understanding heterogeneity in response to treatment and suggests two important conclusions. First, if alternative housing mobility programs were designed to induce moves to neighborhoods with characteristics other than low poverty, it is entirely feasible that such programs might induce larger effects than those realized with MTO. Second, local-average-treatment-effect estimates appear to reconcile the evidence from MTO with prevailing theories of neighborhood effects.

\section{"The Spending and Debt Response to Minimum Wage Hikes"}

Aaronson, Agarwal, and French provide new evidence on the spending and debt responses of consumers to an exogenous income change, in particular an increase in the minimum wage among households with an adult minimum wage worker. They present four key empirical findings based on a variety of large survey and administrative datasets. First, a \$1 per hour minimum wage hike increases total household spending by approximately $\$ 700$ per quarter in the near term. This exceeds the roughly $\$ 250$ per quarter increase in household income resulting from the hike. This pattern is corroborated by independent data showing that debt rises substantially after a minimum wage increase. Second, the majority of this additional spending goes toward durable goods, espe- cially vehicles. Consequently, the spending response is concentrated among a small number of households. Third, total spending increases within one quarter after a minimum wage hike, although legislation of the increase typically passes 6 to 18 months before the hike. Finally, high levels of durables spending and debt accumulation persist for several quarters after a minimum wage hike.

Aaronson, Agarwal, and French argue that these results are hard to explain using two canonical models: the permanent income model and the buffer-stock model with no borrowing. If households were spreading an income gain over their lifetime, as in the permanent income hypothesis, the short-run spending increase should be much smaller than what is observed in the data. The authors show that augmenting the permanent income model to account for durables raises the predicted short-term spending response. However, it is still an order of magnitude smaller than what the empirical estimates imply. Moreover, a bufferstock model in which households cannot borrow against durable goods generates a spending response of less than $\$ 200$ per quarter and fails to explain why some minimum wage households increase their debt after a minimum wage hike.

The authors further consider an augmented buffer-stock model in which households are collateral constrained; that is, they can borrow against part, but not all, of the value of their durable goods. If households face collateral constraints, small income increases can generate small down payments, which in turn can be used for large durable goods purchases. For example, with a 20 percent down payment, each additional dollar of income can purchase $\$ 5$ of durable goods. Such a model does much better matching the facts, including for the magnitude, composition, and timing of spending and debt. An augmented buffer-stock model that allows for the cost of adjusting durables (e.g., the time it takes to shop for a new car or the trade-in value of a vehicle) also replicates the skewness of the spending responses shown in the data. The authors' results provide direct microeconomic evidence of the quantitative importance of collateral constraints, a factor increasingly used to understand the 
dynamics of consumer durables, housing, and entrepreneurship.

\section{"Designing Formulas for Distributing State Aid Reductions"}

Zhao and Coyne present a new framework for distributing state aid to local governments. Given the ongoing state and local fiscal crises across the nation, state aid to local governments has become an increasingly important and contentious budgetary issue. States tend to disproportionately and quickly cut local aid during a fiscal crisis. Indeed, the Congressional Budget Office reports that 22 states reduced aid to local governments in fiscal year 2010 and that 20 states propose additional cuts in fiscal year 2011. Some states cut aid on an ad hoc basis, while others cut aid across the board, with every community receiving the same percent or per capita dollar cut. Such approaches are widely considered unfair: Critics say ad hoc approaches are not based on economic rationale and lack transparency in the decisionmaking process and that across-the-board cuts are more burdensome for poorer communities that tend to rely more heavily on state aid.

To address these concerns, Zhao and Coyne develop a framework that reduces aid distribution based on underlying local fiscal health. They use a local fiscal gap measure to indicate fiscal health outside the direct control of local officials. Based on this framework, state government would cut less aid from communities with larger fiscal gaps and less existing aid. The framework also accommodates aid increases, thus providing policymakers with a single tool for aid revision. The authors use Massachusetts data on unrestricted municipal aid to conduct simulations and explore policy implications.

Unlike the Zhao-Coyne framework, the current literature on state aid distribution focuses on gap-based formulas that preserve existing aid distributions, or hold them harmless, and distribute only aid increases. Therefore, those formulas are incompatible with aid-reduction scenarios.

The Zhao-Coyne analysis is useful for policymaking and discussion. First, it provides a more rational and fair framework for cutting local aid than commonly used ad hoc or across-the-board methods. Adopting their gap-based framework for aid reduction can help reduce the burden for communities with the worst underlying fiscal health and, therefore, advance fiscal equalization across cities and towns. Second, the framework helps the transition from non-gap-based to gapbased aid distribution even in years of aid cuts: States can accelerate the reform process (without waiting for aid increases) to implement a gapbased formula with a hold-harmless clause. Third, the research is practical and timely because many states are making or planning to make additional local aid cuts. The framework can be used for distributing school or non-school aid and is potentially applicable to all states.

\section{"The Role of Schools in the Production of Achievement"}

The literature on sources of inequality finds that "pre-market" factors (i.e., skills individuals acquire before entering the labor market) explain most income inequality across individuals and between groups of individuals. But what explains differences in pre-market factors? Three types of inputs are believed to determine these factors: ability, family inputs, and school inputs. Therefore, to answer the question it is crucial to understand first the relative importance of each input.

A growing literature in economics tries to provide an answer to the question by studying children's scores on performance tests. The literature on the production of achievement has not been able to provide an estimation that simultaneously accounts for the three factors at the student level. Canon intends to fill this gap by providing an estimation of the production function of achievement where both investment types (families and schools) are considered in a framework in which the inputs are allowed to be correlated with the unobserved term: ability to learn. Canon does so by applying an algorithm, which accommodates endogeneity problems in the choice of inputs for the production of achievement, to a very suitable dataset for this problemthe National Education Longitudinal Study of 1988 (from the Institute of Education Sciences, U.S. Department of Education). 
This dataset provides information on both home and school inputs at the student level as well as parents' savings for their children's postsecondary education. Canon uses the savings data to control for the unobserved component (i.e., the ability to learn) in the production of skills. This allows recovery of the parameters of interest in the production function of achievement: the effect of period-by-period investment and the impact of the achievement acquired in previous periods. What makes the savings for postsecondary education measure informative is that parents decide to save at the same time they choose the family and school inputs that will affect the observed test score (the current outcome). However, those savings will not affect the current outcome but instead will affect future labor market outcomes through the choice to attend college.

Canon's estimates for the role of family inputs are in line with previous findings: They foster students' achievement and these inputs are more crucial at some times than others. However, her estimates of school inputs show that, contrary to what has been found in the existing literature, they are important for the formation of students' skills. Moreover, school inputs seem to be as important as family inputs if late remediation policies are considered. Additionally, Canon also finds evidence that savings for postsecondary education are a good proxy for students' unobserved ability to learn.

\section{"Economic Literacy and Inflation Expectations: Evidence from a Laboratory Experiment"}

Burke and Manz present new experimental evidence on heterogeneity in the formation of inflation expectations and relate the variation to economic literacy and demographics. They conduct a laboratory experiment in which subjects complete a set of inflation-forecasting exercises in a simulated economic environment. Subjects complete (i) a questionnaire that measures economic and financial literacy and (ii) two simulation exercises that require them to provide forecasts of near-term and medium-term inflation for the U.S. economy. In the first exercise, sub- jects select information from a menu of information sources with varying degrees of economic relevance; in the other, they receive preselected, uniform information sets. These separate exercises identify two important sources of heterogeneity across individuals with respect to expectations formation: (i) differences in the types of information used in forming inflation expectations (i.e., information is selected by the subjects) and (ii) differences in the use of identical information when forming inflation expectations (i.e., information is chosen for the subjects).

Burke and Manz find that heterogeneity in information selection significantly increases the variability of forecasting performance compared with the case in which information is homogeneous. This finding suggests that models of the inflation-expectations process vary across subjects, and this variability may contribute to realworld disagreement (and aggregate biases) in inflation expectations.

Compared with previous studies of survey data, the authors find that fewer demographic and socioeconomic factors are associated with variation in inflation expectations. For example, they do not observe robust gender differences in inflation expectations. In some cases, apparent demographic variation in expectations-such as between African Americans and whites-is explained by variation in economic literacy. More important, economic literacy contributes significantly to the accuracy of inflation forecasts and is associated with a reduced tendency to overestimate inflation in particular. The impact of literacy is nonlinear, however: Very poor performance in the bottom quartile of the distribution drives much of the variation, and the marginal impact of literacy becomes negligible above the 75 th or 80th percentile. The contribution of economic literacy is not reducible to overall educational attainment or socioeconomic status and instead reflects a combination of economic knowledge and general numeracy.

Burke and Manz find that economic literacy contributes to the accuracy of forecasts through both sources of heterogeneity described above. First, more-literate subjects choose better (morerelevant) information sources in making their 
forecasts. For example, compared with lessliterate individuals, they are more likely to view data on aggregate inflation and less likely to rely exclusively on information about price changes for specific goods such as milk and oil. Second, more-literate subjects make better use of given data in the exercises involving preselected information. The results suggest that modest educational interventions targeted at individuals with very low economic literacy levels could lead to significant improvements in inflation forecasting. For example, directing subjects to more-relevant information, such as recent data on aggregate inflation rather than specific price changes, may reduce forecasting errors considerably.

\section{"Financial Literacy and Mortgage Equity Withdrawals"}

Duca and Kumar assert that mortgage equity withdrawals (MEWs) have been linked to the U.K. consumption boom of the late 1980s and the U.S. consumption boom of the early 2000s. MEWs have been linked to an increased sensitivity of consumption to housing wealth and liquidity constraints, consistent with permanent income models incorporating credit constraints, which imply that housing wealth influences consumption by providing collateral for loans to otherwise credit-constrained families.

However, the recent mortgage bust suggests that many households were unaware of the risks they took with MEWs, which is consistent with evidence that many are financially illiterate. Using data from the Health and Retirement Study (sponsored by the National Institute on Aging), earlier research documents that many families incorrectly answered questions about compound interest, money illusion, and portfolio diversification. Incorrect answers have been linked to suboptimal saving for retirements, overborrowing, and low stock market participation. Previous research indicates that state-mandated high school financial education and employer-based financial literacy programs led to higher saving. In addition, there is evidence that many homeowners do not choose the lowest-cost home mortgage option because they may be confused by terms in mortgage contracts. Despite a role for increased MEWs during the recent boom and bust in consumption, potential linkages between financial literacy and MEWs are yet unexplored.

Duca and Kumar address this gap by examining whether financial literacy is linked to MEWs. Using three different measures of financial literacy-compound interest, money illusion, and portfolio diversification-they find that individuals' knowledge of portfolio diversification has the most significant impact on their propensity to make MEWs. The authors' results indicate that the financially literate are 3 to 5 percentage points less likely to withdraw housing equity by increasing mortgage debt; however, this result does not apply to their tapping home equity lines of credit. The authors also find that the propensity to make MEWs rises with house price appreciation and incentives to lower mortgage interest rates. In line with earlier research, the findings of Duca and Kumar indicate that legal conditions across states are correlated with MEW behavior. Given the recent evidence in the literature that MEWs were correlated with mortgage delinquencies as the housing crisis deepened, the DucaKumar findings suggest that financial education programs might be effective in preventing mortgage defaults.

\section{"When Does the Labor Market Consider You a Smoker and Do You Care?"}

Armour, Hotchkiss, and Pitts investigate when the labor market considers an individual a smoker, how being a smoker affects earnings, and how the expected earnings differential affects an individual's propensity to smoke. ${ }^{2}$ They use a switching regression with an unknown sampleselection framework that allows for the data to indicate when the labor market begins treating workers differently based on whether they smoke. Their analysis is performed using data from the annual Current Population Survey Tobacco Use Supplement (from the Bureau of Labor Statistics) for 2000 to 2007.

\footnotetext{
2 The authors' paper and this summary do not represent the views of the Centers for Disease Control and Prevention.
} 
Their analysis indicates that the labor market classifies an individual who smokes at all as a smoker. This suggests that even the most casual smokers experience wage penalties for smoking. Furthermore, the characteristics of smokers reduce the wage penalty, indicating that the wage differential is not a result of smokers bringing less-productive endowments to the labor market. Instead, the differential is from employers placing less value on the endowments brought by smokers than the same endowments brought by nonsmokers (the coefficient effect is positive), indicating that employers treat smokers differently than nonsmokers.

The analysis also indicates that individual smoking behavior responds to the labor market penalty associated with smoking. The implication is that policies designed to increase the labor market penalty of smoking could be a powerful tool in reducing smoking. The authors' results remain robust when they compare different types of current nonsmokers with current smokers and estimate the model on a subsample of married people only.

\section{"Financing Constraints and Unemployment: Evidence from the Great Recession"}

Duygan-Bump, Levkov, and MontoriolGarriga assert that lending to small businesses in the United States has fallen dramatically since the onset of the Great Recession. According to the most recent data, small-business loans made by commercial banks declined over $\$ 40$ billion between the second quarter of 2008 and the second quarter of 2010. Similarly, the responses to the Federal Reserve's Senior Loan Officer Opinion Survey on Bank Lending Practices indicate that banks have significantly tightened credit standards on commercial and industrial loans to small firms in 13 consecutive quarters (2007:Q1-2010:Q1).

The decline in small-business lending has received much attention from policymakers, especially because of its potential link to the high unemployment rate. Indeed, almost 80 percent of all firms in the United States have fewer than nine employees, and small firms employ roughly
50 percent of all Americans. Unlike larger firms, which have broader access to capital markets, small businesses are highly dependent on bank financing. Accordingly, smaller firms are likely to have been disproportionately affected when banks restricted credit following shocks to their balance sheets.

The authors investigate the link between small-business lending and unemployment during the Great Recession. They argue that if reductions in small-business lending affect unemployment, then unemployment would be expected to increase more in smaller firms, but only among firms that depend on bank financing. They test their hypothesis by exploiting variation across firm size and external financial dependence. Specifically, they combine information on workers' firm size and unemployment status from the Current Population Survey (from the Bureau of Labor Statistics) with firms' financial information from Compustat and the Survey of Small Business Finances (from the Board of Governors of the Federal Reserve System). They then estimate changes in the unemployment rate during the recent financial crisis by firm size and across industrial sectors with different degrees of financial need.

Duygan-Bump, Levkov, and MontoriolGarriga find that during the Great Recession workers in sectors with high external financial dependence were more likely to become unemployed, especially workers in smaller firms. By contrast, the authors do not find significant differences in unemployment propensity between workers in small and large firms in sectors with low external financial dependence. They estimate that during the financial crisis the likelihood of unemployment among workers in small, financially constrained firms increased by 0.55 percentage points relative to other workers. One explanation of this finding is that the financial crisis propagated to the real economy through a reduction in bank credit.

An alternative explanation of their finding is that changes in unemployment are not driven by changes in the supply of credit, but rather reflect a disproportionate reduction in the demand for goods and services produced by finance-dependent 


\section{Garrett}

sectors. To address this possible explanation, the authors repeat their analyses using data around the 2001 recession. They exploit the fact that the 2001 recession did not originate from stressed bank balance sheets. The resulting estimates for that recession show almost identical changes in the unemployment rate among small and large firms with different degrees of financial dependence. Comparison of the 2007-09 and 2001 recessions indicates that changes in the supply of credit contributed to changes in the rate of unemployment during the recent financial crisis.
This paper has important implications for policy intervention. The authors suggest that policies aimed at making credit available to small businesses, such as the recent $\$ 30$ billion Small Business Jobs Act or the loans guaranteed by the Small Business Administration, would help stabilize the labor markets and economic activity in the United States.

\section{REFERENCES}

Aaronson, Daniel; Agarwal, Sumit and French, Eric. "The Spending and Debt Response to Minimum Wage Hikes.” Working Paper No. 2007-23, Federal Reserve Bank of Chicago, February 2011; www.chicagofed.org/webpages/publications/working papers/2007/wp 23.cfm.

Aliprantis, Dionissi. “Assessing the Evidence on Neighborhood Effects from Moving to Opportunity.” Federal Reserve Bank of Cleveland, Working Paper No. 11-01, January 2011; www.clevelandfed.org/research/workpaper/2011/wp1101.pdf.

Armour, Brian S.; Hotchkiss, Julie L. and Pitts, M. Melinda. "When Does the Labor Market Consider You a Smoker and Do You Care?” Unpublished manuscript, Federal Reserve Bank of Atlanta, 2011.

Burke, Mary A. and Manz, Michael. "Economic Literacy and Inflation Expectations: Evidence From a Laboratory Experiment.” Unpublished manuscript, Federal Reserve Bank of Boston, 2011.

Canon, Maria E. “The Role of Schools in the Production of Achievement.” Working Paper No. 2010-042A, Federal Reserve Bank of St. Louis, October 2010; http://research.stlouisfed.org/wp/more/2010-042.

Duca, John V. and Kumar, Anil. "Financial Literacy and Mortgage Equity Withdrawals.” Unpublished manuscript, Federal Reserve Bank of Dallas, December 2010.

Duygan-Bump, Burcu; Levkov, Alexey and Montoriol-Garriga, Judit. "Financing Constraints and Unemployment: Evidence from the Great Recession.” Working Paper No. QAU10-6, Federal Reserve Bank of Boston, October 2011; www.bos.frb.org/bankinfo/qau/wp/2010/qau1006.htm.

Zhao, Bo and Coyne, David. "Designing Formulas for Distributing State Aid Reductions.” New England Public Policy Center Working Paper No. 11-2, Federal Reserve Bank of Boston, 2011; www.bos.frb.org/economic/neppc/wp/2011/neppcwp112.htm. 